\title{
Interaction of drugs with lipid raft membrane domains as a possible target
}

\author{
Hironori Tsuchiya ${ }^{1}$, Maki Mizogami² \\ ${ }^{1}$ Asahi University School of Dentistry, Mizuho, Gifu - Japan \\ ${ }^{2}$ Department of Anesthesiology, Kizawa Memorial Hospital, Minokamo, Gifu - Japan
}

\begin{abstract}
Introduction: Plasma membranes are not the homogeneous bilayers of uniformly distributed lipids but the lipid complex with laterally separated lipid raft membrane domains, which provide receptor, ion channel and enzyme proteins with a platform. The aim of this article is to review the mechanistic interaction of drugs with membrane lipid rafts and address the question whether drugs induce physicochemical changes in raft-constituting and raftsurrounding membranes.

Methods: Literature searches of PubMed/MEDLINE and Google Scholar databases from 2000 to 2020 were conducted to include articles published in English in internationally recognized journals. Collected articles were independently reviewed by title, abstract and text for relevance.

Results: The literature search indicated that pharmacologically diverse drugs interact with raft model membranes and cellular membrane lipid rafts. They could physicochemically modify functional protein-localizing membrane lipid rafts and the membranes surrounding such domains, affecting the raft organizational integrity with the resultant exhibition of pharmacological activity. Raft-acting drugs were characterized as ones to decrease membrane fluidity, induce liquid-ordered phase or order plasma membranes, leading to lipid raft formation; and ones to increase membrane fluidity, induce liquid-disordered phase or reduce phase transition temperature, leading to lipid raft disruption.

Conclusion: Targeting lipid raft membrane domains would open a new way for drug design and development. Since angiotensin-converting enzyme 2 receptors which are a cell-specific target of and responsible for the cellular entry of novel coronavirus are localized in lipid rafts, agents that specifically disrupt the relevant rafts may be a drug against coronavirus disease 2019 .
\end{abstract}

Keywords: Drug target, Fluidity, Lipid raft, Membrane domain, Membrane interaction

\section{Introduction}

Since Singer and Nicolson proposed a fluid mosaic model, the concept of membrane organization has progressively changed, that is, plasma membranes are not the homogeneous bilayers of uniformly distributed lipids but the lipid complex with laterally separated membrane domains such as lipid rafts and caveolae (1). Lipid rafts are small (10-200 nm), heterogeneous, dynamic, and cholesterol- and sphingolipidenriched membrane domains that are distinct from the rest

Received: September 17, 2020

Accepted: November 11, 2020

Published online: December 22, 2020

Corresponding author:

Hironori Tsuchiya

Asahi University School of Dentistry

1851 Hozumi, Mizuho, Gifu 501-0296 - Japan

tsuchi-hiroki16@dent.asahi-u.ac.jp of the membrane structures (2), whereas caveolae are a subset of lipid rafts and organizationally maintained by characteristic protein caveolins (3). Lipid rafts in a liquid-ordered $\left(L_{0}\right)$ phase coexist with the bulk of membranes in a liquiddisordered $\left(L_{d}\right)$ phase (4). Lipid raft membrane domains play an important role in cellular signal transduction and trafficking by compartmentalizing membranes and providing functional membrane proteins with a platform (4-7). Pharmacologically relevant receptors, ion channels and enzymes are localized or cluster in membrane lipid rafts and caveolae (8-11).

Given the localization of receptors, ion channels and enzymes in membrane lipid rafts, the mode of drug action is first interpretable in a simple manner of receptor/channel/ enzyme and ligand interaction as known in the conventional mechanistic theory. The second possibility is that drugs may act on membrane lipids to affect the organizational integrity of lipid rafts, resulting in modulation of the activity of receptors, ion channels and enzymes embedded in membrane domains. It is of much interest to know whether drugs interact 
preferentially with lipid rafts compared with non-raft overall membrane lipid bilayers and whether such interaction at a membrane lipid level is linked to pharmacological and cytotoxic effects of drugs. While cholesterol is essential to raft and caveola formation, the regulatory effects of membrane domains on receptors and ion channels were confirmed by depleting cholesterol in plasma membranes (12-15).

The purpose of the present study is to review the interaction of drugs with membrane lipid rafts and the membranes surrounding such domains by searching scientific articles from a mechanistic point of view in order to gain new insights into a drug target. Since various proteins embedded in membranes are functionally modulated by membrane fluidity, order and phase transition, the focus of our review is on addressing the question whether drugs modify the physicochemical properties of raft-constituting and raft-surrounding membranes to affect the formation, stability and integrity of lipid raft membrane domains.

\section{Methods}

The present review is based on articles that were retrieved from PubMed/MEDLINE and Google Scholar by searching databases from 2000 to 2020. The publications earlier than 2000 were exceptionally cited if they are essential to advancing the discussion. Research papers published in English in internationally recognized journals and online journals were preferred, but review articles were additionally used to deepen understanding of the concept of plasma membranes and the mode of drug action. For reviewing as diverse drugs as possible without confining to a specific class of drug, the literature searches were carried out using the following terms or combinations thereof: "lipid raft," "caveola," "membrane domain," "membrane interaction," "fluidity," "receptor," "channel" and "enzyme." Collected articles were independently reviewed by title, abstract and text for relevance with preference to more recent publications.

\section{Results and discussion}

\section{Drug and raft interaction methodology}

Since the methodology of drug and membrane raft interaction is essential to facilitate readers' understanding of individual studies, representative experiments are mentioned as follows.

In in vitro experiments, drugs are subjected to the reaction with raft model (raft-like) membranes or liposomes that mimic the lipid composition and property of lipid raft micro domains $(16,17)$. Ternary lipid membranes are used as a raft model, which is frequently prepared with an equimolar mixture of 1-palmitoyl-2-oleoylphosphatidylcholine (POPC), sphingomyelin (SM) and cholesterol (18), in which cholesterol functions as a spacer between sphingolipid hydrocarbon chains and as a glue to keep the raft assembly together (19). Such raft model membranes have the advantage that the membrane effects of drugs can be determined more easily than in vivo experiments (20). Lipid rafts isolated from cells are also used experimentally. Since lipid rafts are relatively insoluble in cold non-ionic detergents, cells are treated with Triton X-100 and membrane lipid rafts are fractionated by sucrose density gradient centrifugation (SDGC) (21).

In in vivo experiments, human and animal subjects are treated with drugs, followed by SDGC to isolate cellular membrane lipid rafts. Cholesterol is not only a critical determinant for membrane fluidity but also an essential component to form the $L_{0}$ membrane domains. Cellular cholesterol contents are manipulated by treating animals with cholesterol metabolic inhibitors, culturing cells in cholesterol-deficient media and using cholesterol-depleting agents. Methyl- $\beta$ cyclodextrin (MBC), to form a 2:1 complex with cholesterol (22), is most widely used for cholesterol depletion (23).

Drug-induced physicochemical or biophysical changes in raft model membranes and membrane lipid rafts are determined by fluorescence polarization (FP) or anisotropy (FA), differential scanning calorimetry (DSC), nuclear magnetic resonance (NMR) spectroscopy, neutron diffraction (ND), $X$ ray diffraction (XD) and their complementary combination.

\section{General anesthetics}

General anesthetics and their related sedatives, anxiolytics and adjuncts act on inhibitory $\gamma$-aminobutyric acid type A $\left(G_{A B A}\right)$ receptors and excitatory $N$-methyl-D-aspartate (NMDA) receptors (24). Intravenous and inhalational anesthetics are a positive allosteric modulator or a direct activator of $\mathrm{GABA}_{\mathrm{A}}$ receptors to enhance their inhibitory functions, inducing general anesthesia, sedation, anxiolysis and convulsion cessation (25). Inhalational anesthetics are also a non-competitive antagonist of NMDA receptors to reduce neuronal excitation, producing analgesic, sedative and anesthesia-maintaining effects $(26,27)$. These anesthesiarelevant $\mathrm{GABA}_{\mathrm{A}}$ receptors and NMDA receptors are associated with lipid raft membrane domains $(28,29)$. Results of the literature search indicated that general anesthetics interact with membrane lipid rafts and membranes as shown in Table I.

\section{Intravenous anesthetic propofol}

FP experiments demonstrated that propofol structurespecifically interacts with binary liposomal membranes prepared with $80 \mathrm{~mol} \%$ POPC and 20 mol\% cholesterol (30) and quinary liposomal membranes prepared with 55 mol\% phospholipids (POPC, SM, 1-palmitoyl-2-oleoylphosphatidylethanolamine (POPE) and 1-palmitoyl-2-oleoylphosphatidylserine (POPS)) and $45 \mathrm{~mol} \%$ cholesterol (31), resulting in an increase of membrane fluidity at clinically relevant $0.125-10 \mu \mathrm{M}$. $L_{o}$ and $L_{d}$ phase equilibrium is present in giant plasma membrane vesicles (GPMVs) isolated from rat basophil leukemia cells, which are used as a model of membrane heterogeneity for lipid rafts. Gray et al treated GPMVs with propofol and its structural analogs to examine their effects on liquid-liquid transition by analyzing the lateral distribution of fluorescent probe Dil-C $\mathrm{C}_{12}$ microscopically (32). Propofol reduced the critical transition temperature at 2.5-10 $\mu \mathrm{M}$, but not 2,6-di-tert-butylphenol without the anesthetic activity at the same concentrations. Therefore, propofol is considered 
TABLE I - Interaction of general anesthetics with lipid raft membrane domains and membranes

\begin{tabular}{|c|c|c|c|c|}
\hline Drug class & Drug & Membrane & Induced membrane modification & Reference \\
\hline $\begin{array}{l}\text { Intravenous } \\
\text { anesthetic }\end{array}$ & $\begin{array}{l}\text { Propofol } \\
(0.125-1.0 \mu \mathrm{M})\end{array}$ & $\begin{array}{l}\text { Binary liposomal membranes ( } 80 \text { mol\% } \\
\text { POPC and } 20 \text { mol\% cholesterol) }\end{array}$ & Increased membrane fluidity & 30 \\
\hline $\begin{array}{l}\text { Intravenous } \\
\text { anesthetic }\end{array}$ & Propofol (10 $\mu \mathrm{M})$ & $\begin{array}{l}\text { Quinary liposomal membranes ( } 55 \text { mol\% } \\
\text { phospholipids (POPC, SM, POPE and } \\
\text { POPS) and } 45 \text { mol\% cholesterol) }\end{array}$ & Increased membrane fluidity & 31 \\
\hline $\begin{array}{l}\text { Intravenous } \\
\text { anesthetic }\end{array}$ & Propofol (2.5-10 $\mu \mathrm{M})$ & $\begin{array}{l}\text { GPMVs isolated from rat basophil } \\
\text { leukemia cells }\end{array}$ & $\begin{array}{l}\text { Reduced the critical transition } \\
\text { temperature structure-specifically }\end{array}$ & 32 \\
\hline $\begin{array}{l}\text { Intravenous } \\
\text { anesthetic }\end{array}$ & $\begin{array}{l}\text { Propofol } \\
(10 \text { and } 30 \mu \mathrm{M})\end{array}$ & $\begin{array}{l}\text { Human airway smooth muscle cell } \\
\text { membranes }\end{array}$ & $\begin{array}{l}\text { Reduced the intracellular } \mathrm{Ca}^{2+} \\
\text { concentration responses to } 10 \mu \mathrm{M} \\
\text { histamine, disrupted caveolae and } \\
\text { decreased caveolin-1 expression }\end{array}$ & 33 \\
\hline $\begin{array}{l}\text { Inhalational } \\
\text { anesthetic }\end{array}$ & $\begin{array}{l}\text { Isoflurane } \\
(1 \text { and } 5 \mathrm{mM})\end{array}$ & $\begin{array}{l}\text { POPC/cholesterol liposomal membranes, } \\
\text { erythrocyte ghosts and brain endothelial } \\
\text { cell-mimetic membranes }\end{array}$ & Increased membrane fluidity & 34 \\
\hline $\begin{array}{l}\text { Inhalational } \\
\text { anesthetic }\end{array}$ & $\begin{array}{l}\text { Isoflurane } \\
(2.5-12 \mathrm{mM})\end{array}$ & $\begin{array}{l}\text { LUVs ( } 62.5 \text { mol\% DPPC and } 37.5 \text { mol\% } \\
\text { cholesterol) }\end{array}$ & $\begin{array}{l}\text { Weakened the sterol-phospholipid } \\
\text { association in cholesterol-rich } L_{\circ} \text { phase } \\
\text { membranes }\end{array}$ & 35 \\
\hline $\begin{array}{l}\text { Inhalational } \\
\text { anesthetic }\end{array}$ & $\begin{array}{l}\text { Halothane } \\
(1.5 \mathrm{~mol} \%)\end{array}$ & $\begin{array}{l}\text { Multilayer membranes (DPPC and DLPC, } \\
\text { 1:1 molar ratio) }\end{array}$ & $\begin{array}{l}\text { Reduced the transition temperature by } \\
\text { about } 5^{\circ} \mathrm{C}\end{array}$ & 36 \\
\hline \multirow{4}{*}{$\begin{array}{l}\text { Inhalational } \\
\text { anesthetic }\end{array}$} & Xenon (4.6-fold MAC) & \multirow{4}{*}{$\begin{array}{l}\text { Raft model membranes (DOPC, SM and } \\
\text { cholesterol, 1:1:0.2 molar ratio) }\end{array}$} & \multirow[t]{2}{*}{ Increased the $L_{d}$ phase } & \multirow[t]{4}{*}{37} \\
\hline & $\begin{array}{l}\text { Nitrous oxide } \\
\text { (4.6-fold MAC) }\end{array}$ & & & \\
\hline & $\begin{array}{l}\text { Halothane (three- to } \\
\text { fivefold MAC) }\end{array}$ & & \multirow[t]{2}{*}{$\begin{array}{l}\text { Decreased the relative intensity of } L_{o} \text { to } \\
L_{d} \text { phase }\end{array}$} & \\
\hline & $\begin{array}{l}\text { Isoflurane (three- } \\
\text { to fivefold MAC) }\end{array}$ & & & \\
\hline Barbiturate & $\begin{array}{l}\text { Rats injected with } \\
\text { sodium pentobarbital } \\
\text { (50 mg/kg, i.p.) }\end{array}$ & $\begin{array}{l}\text { Lipid rafts isolated from rat brains } \\
15 \text { minutes after drug injection }\end{array}$ & Reduced the transition temperature & 38 \\
\hline
\end{tabular}

$\mathrm{DLPC}=1$ 2-dilauroylphosphatidylcholine; DOPC $=1,2$-dioleoylphosphatidylcholine; DPPC $=1,2$-dipalmitoylphosphatidylcholine; GPMV $=$ giant plasma membrane vesicle; $L U V=$ large unilamellar vesicle; $M A C=$ minimum alveolar concentration; POPC = 1-palmitoyl-2-oleoylphosphatidylcholine; POPE = 1-palmitoyl2-oleoylphosphatidylethanolamine; POPS = 1-palmitoyl-2-oleoylphosphatidylserine; SM = sphingomyelin.

to decrease the magnitude of membrane heterogeneity structure-specifically, affecting receptor and ion channel proteins sensitive to raft heterogeneity. While propofol is known to produce bronchodilatation, the airway relaxation involves a decrease of $\mathrm{Ca}^{2+}$ concentrations in airway smooth muscle cells that are regulated by caveolae. By exposing human airway smooth muscle cells to propofol at 10 and $30 \mu \mathrm{M}$, Grim et al found that propofol increases in membrane caveolae and reduces the intracellular $\mathrm{Ca}^{2+}$ concentration response to $10 \mu \mathrm{M}$ histamine (33). They also suggested that propofol may induce caveolar disruption and caveolin-1 expression decrease.

\section{Inhalational anesthetics}

Patel et al investigated the membrane effects of isoflurane using different membrane systems such as POPC/cholesterol liposomal membranes, erythrocyte ghosts and brain endothelial cell-mimetic membranes (34). FA measurements indicated that isoflurane increases the membrane fluidity at 1 and $5 \mathrm{mM}$. Turkyilmaz et al prepared large unilamellar vesicles (LUVs) with 1,2-dipalmitoylphosphatidylcholine (DPPC) and cholesterol to be $2.5 \mathrm{~mol} \%$ or $37.5 \mathrm{~mol} \%$ cholesterolcontaining DPPC membranes to verify the membrane effects of inhalational anesthetics (35). Isoflurane and halothane weakened and strengthened the sterol-phospholipid association in cholesterol-rich $L_{\text {, }}$ phase membranes and in cholesterol-poor $L_{d}$ phase membranes, respectively, at 2.5-12 mM. In ND and XD experiments of Weinrich et al, halothane was subjected to the reaction with multilayer membranes that were prepared with an equimolar mixture of DPPC and 1,2-dilauroylphosphatidylcholine (DLPC) to form distinct DPPC-rich ordered and DLPC-rich fluid phase (36). Halothane reduced the transition temperature by about $5^{\circ} \mathrm{C}$ at $1.5 \mathrm{~mol} \%$ corresponding to about twice the minimum alveolar concentration (MAC) for human anesthesia, but not non-anesthetic 
1,2-dichlorohexafluorocyclobutane even at fivefold MAC. Weinrich and Worcester determined the effects of different anesthetics on liquid phase distribution in raft model membranes prepared with 1,2-dioleoylphosphatidylcholine (DOPC), SM and cholesterol (1:1:0.2 molar ratio) by ND and XD analysis (37). Xenon and nitrous oxide increased the $L_{d}$ phase at 4.6-fold MAC, and halothane and isoflurane decreased the relative intensity of $L_{o}$ to $L_{d}$ phase at three- to fivefold MAC.

\section{Barbiturate}

Pentobarbital is intravenously and intraperitoneally administered especially in veterinary anesthesia or sedation. Sierra-Valdez et al characterized the in vivo effects of pentobarbital on rat brain lipid rafts, which were isolated $15 \mathrm{~min}$ after injecting rats with sodium pentobarbital at $50 \mathrm{mg} / \mathrm{kg}$ intraperitoneally (38). DSC analysis revealed that pentobarbital reduces the transition temperature from $L_{o}$ to $L_{d}$ phase.

\section{Membranous sodium channel blocker local anesthetics}

Local anesthetics reversibly block voltage-gated sodium (Nav) channels that are responsible for the initiation and propagation of action potentials in excitable cells, inhibiting sensory and motor functions (39). Among nine distinct Nav channels (Nav1.1 to Nav1.9) cloned from mammals, Nav1.8 channel plays a crucial role in pain transmission and this isoform is implicated as a site of action for anesthetic and analgesic drugs. While Nav channels are present in caveolae-type and non-caveolae-type lipid rafts, Nav1.8 channel clustering in such membrane domains is essential to the propagation of action potentials in nociceptive axons $(40,41)$. Nav1.8 channels are associated with lipid rafts in rat dorsal root ganglionic neurons, but cholesterol depletion induces dissociation between Nav1.8 channels and lipid rafts (42). Results of the literature search on the interaction of local anesthetics with membrane lipid rafts and membranes are shown in Table II.

Kamata et al incubated human erythrocytes with lidocaine at $18.4 \mathrm{mM}$ and prepared erythrocyte ghosts, followed by SDGC fractionation and immunoblotting analysis for flotillin-1 (caveolae-associated integral membrane protein) that is assumed to stabilize lipid rafts (43). Lidocaine reversibly disrupted erythrocyte membrane lipid rafts and abolished flotillin-1 in lipid rafts together with depleting cholesterol. Bandeiras et al treated LUVs prepared with POPC, SM and cholesterol (1:1:1 molar ratio) with tetracaine and lidocaine, and then evaluated their membrane effects by DSC and phosphorus NMR spectroscopy (44). Tetracaine and lidocaine increased the fluidity of raft-like membranes at 25 and $69 \mathrm{mM}$,

TABLE II - Interaction of membranous sodium channel blocker local anesthetics with lipid raft membrane domains and membranes

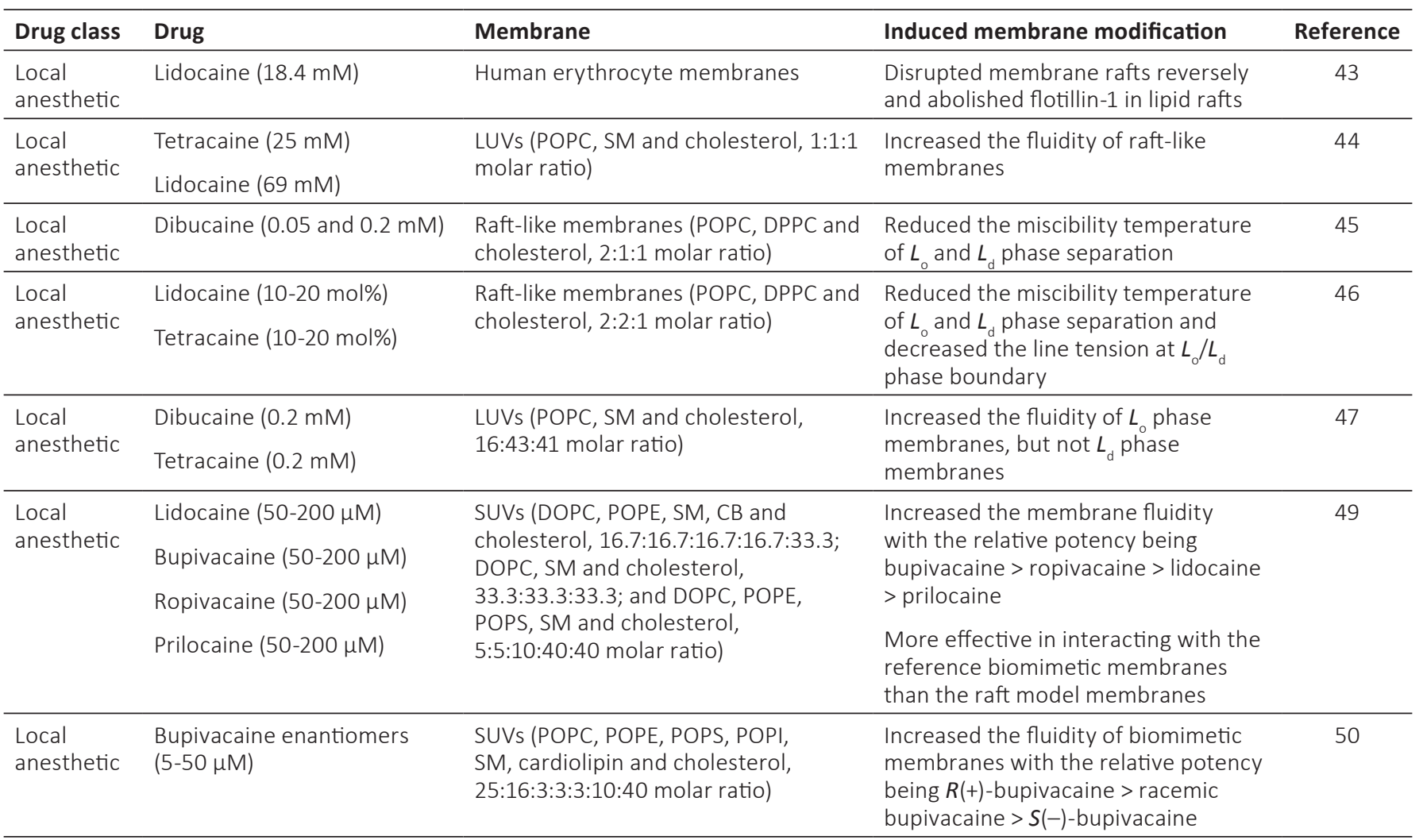

$\mathrm{CB}=$ cerebroside; DOPC = 1,2-dioleoylphosphatidylcholine; DPPC = 1,2-dipalmitoylphosphatidylcholine; LUV = large unilamellar vesicle; POPC = 1-palmitoyl2-oleoylphosphatidylcholine; POPE = 1-palmitoyl-2-oleoylphosphatidylethanolamine; POPI = 1-palmitoyl-2-oleoylphosphatidylinositol; POPS = 1-palmitoyl2-oleoylphosphatidylserine; SM = sphingomyelin; SUV = small unilamellar vesicle. 
respectively. Yoshida et al prepared lipid bilayer membranes with DOPC, DPPC and cholesterol (2:1:1 molar ratio) to be laterally separated into $L_{0}$ and $L_{d}$ phase together with labeling the membranes with fluorescent probe rhodamine DHPE (dihexadecanoyl-sn-glycero-3-phosphoethanolamine) (45). After treating the membrane preparations with dibucaine at 0.05 and $0.2 \mathrm{mM}$, they observed the raft-like membrane domains by fluorescence microscopy at $20-40^{\circ} \mathrm{C}$ to determine changes in miscibility temperature of the $L_{o}$ and $L_{d}$ phase separation and in line tension at the $L_{0} / L_{d}$ phase boundary. Dibucaine reduced the miscibility temperature, which was accompanied by the line tension decrease. Dibucaine also made the $L_{o}$ domains smaller at $25^{\circ} \mathrm{C}$, although most membranes were present without such raft-like domains at above $25^{\circ} \mathrm{C}$. In a similar microscopic experiment using liposomes prepared with DOPC, DPPC and cholesterol (2:2:1 molar ratio), lidocaine and tetracaine reduced the miscibility temperature of ternary membranes at $10-20$ mol\% relative to liposomal lipids, but not binary membranes without cholesterol (46). Both local anesthetics also decreased the line tension at the $L_{o} / L_{d}$ phase boundary. Kinoshita et al performed FA experiments to reveal the effects of local anesthetics on raft-like $L_{o} /$ non-raft $L_{d}$ phase membranes by using LUVs that were prepared with DOPC, SM and cholesterol (16:43:41 and 65:16:19 in molar ratio for $L_{0}$ phase and $L_{d}$ phase, respectively) (47). Dibucaine disordered the lipid packing or increased the fluidity of $L_{0}$ phase membranes at $0.2 \mathrm{mM}$ more potently than tetracaine, whereas dibucaine and tetracaine showed no significant effects on $L_{d}$ phase membranes. However, these studies (43-47) used drug concentrations much higher than clinically and experimentally relevant ones (48) and the tested dibucaine and tetracaine are not widely used in clinical anesthesia.

Tsuchiya et al prepared small unilamellar vesicles (SUVs) with DOPC, POPE, SM, cerebroside (CB) and cholesterol (16.7:16.7:16.7:16.7:33.3 molar ratio); DOPC, SM and cholesterol (33.3:33.3:33.3 molar ratio); and DOPC, POPE, POPS, SM and cholesterol (5:5:10:40:40 molar ratio) for raft model membranes, and POPC, POPE, POPS, 1-palmitoyl2-oleoylphosphatidylinositol (POPI), SM, cardiolipin and cholesterol (25:16:3:3:3:10:40 molar ratio) for reference biomimetic membranes $(49,50)$. They treated these membrane preparations with lidocaine, bupivacaine, ropivacaine and prilocaine at anesthetic and cardiotoxic concentrations, followed by FP measurements. All the tested anesthetics interacted with raft model and biomimetic membranes to increase the membrane fluidity at $50-200 \mu \mathrm{M}$ with the relative potency being bupivacaine $>$ ropivacaine $>$ lidocaine $>$ prilocaine (49). They were more effective in interacting with the reference membranes than the raft membranes. Biomimetic membranes showed different interactivity with the relative potency being $R(+)$-bupivacaine > racemic bupivacaine > $S(-)$-bupivacaine at 5-50 $\mu \mathrm{M}$, being consistent with the rank order of their anesthetic and cardiotoxic effects (50). However, raft model membranes did not exhibit significant enantioselectivity as the reference biomimetic membranes. These results may suggest that lipid rafts are less likely to contribute at least to the enantioselective effects of local anesthetics.

\section{Membranous receptor- and enzyme-acting drugs}

Results of the literature search on the interaction of receptor-acting adrenergic and opioid drugs and enzymeacting anti-inflammatory drugs with membrane lipid rafts and membranes are shown in Table III.

\section{Beta-adrenergic blockers}

Beta-blockers are perioperatively used to reduce the risk of myocardial ischemia, arrhythmia and cardiac morbidity during anesthesia. Lipid raft/caveola domains encompass $\beta_{2}$ adrenergic receptors, but not $\beta_{1}$-adrenergic receptors for signal transduction $(12,51)$. Mizogami et al prepared SUVs with POPC, SM, POPE, CB and cholesterol (1:1:1:1:2 molar ratio) to compare the membrane effects between different $\beta$-blockers at 0.2 and $1 \mathrm{mM}$ by measuring FP (52). Nonselective propranolol most potently increased the fluidity of raft model membranes, followed by alprenolol and oxprenolol, but not $\beta_{1}$-selective atenolol, metoprolol and esmolol. In a similar FP study using SUVs prepared with 33.3 mol\% cholesterol and 66.7 mol\% phospholipids consisting of equimolar DOPC, SM, POPE and $C B$, nonselective propranolol and alprenolol increased the fluidity of raft model membranes at 20-200 $\mu \mathrm{M}$, whereas $\beta_{1}$-selective landiolol and esmolol were not effective even at $200 \mu \mathrm{M}$ (53). Nonselective $\beta$-blockers could reduce the activity of $\beta_{2}$-adrenergic receptors by fluidizing the membrane lipid rafts together with antagonizing $\beta_{1}$-adrenergic receptors by interacting with $\beta_{1}$-adrenergic receptor proteins, producing nonselective blockade of $\beta$-adrenergic receptors. In contrast, selective $\beta_{1}$-blockers do not affect $\beta_{2}$-adrenergic receptors through interaction with lipid rafts, thereby enhancing the selectivity for $\beta_{1}$-adrenergic receptors.

Beta-blockers, particularly $\beta_{1}$-selective agents, have been used for treating hypertension (54). Although the altered vascular signaling processes are implicated in hypertension, whether lipid rafts/caveolae are responsible for such pathogenic events remains unclear (55), so no significant interaction between antihypertensive drugs and lipid rafts was found in the literature.

\section{Alpha-adrenergic agonists}

Alpha ${ }_{2}$-agonists with the sedative, analgesic, anestheticsparing and sympatholytic activity are used as an adjuvant for anesthesia. Mizogami and Tsuchiya performed FP experiments to investigate their effects on SUVs that were prepared with 33.3 mol\% cholesterol and 66.7 mol\% phospholipids (consisting of equimolar DOPC, SM, POPE and CB) to be raft model membranes and with cholesterol and phospholipids of different compositions to be neuro-mimetic and cardiomyocyte-mimetic membranes (56). Dexmedetomidine interacted with the non-raft membranes to increase their fluidity most potently at 5-200 $\mu \mathrm{M}$, followed by levomedetomidine and clonidine. However, these $\alpha_{2}$-agonists exerted much weaker effects on the raft model membranes so that dexmedetomidine and levomedetomidine did not show large difference in membrane interactivity despite being significantly different in sedative activity between medetomidine enantiomers. 
TABLE III - Interaction of membranous receptor- and enzyme-acting drugs with lipid raft membrane domains and membranes

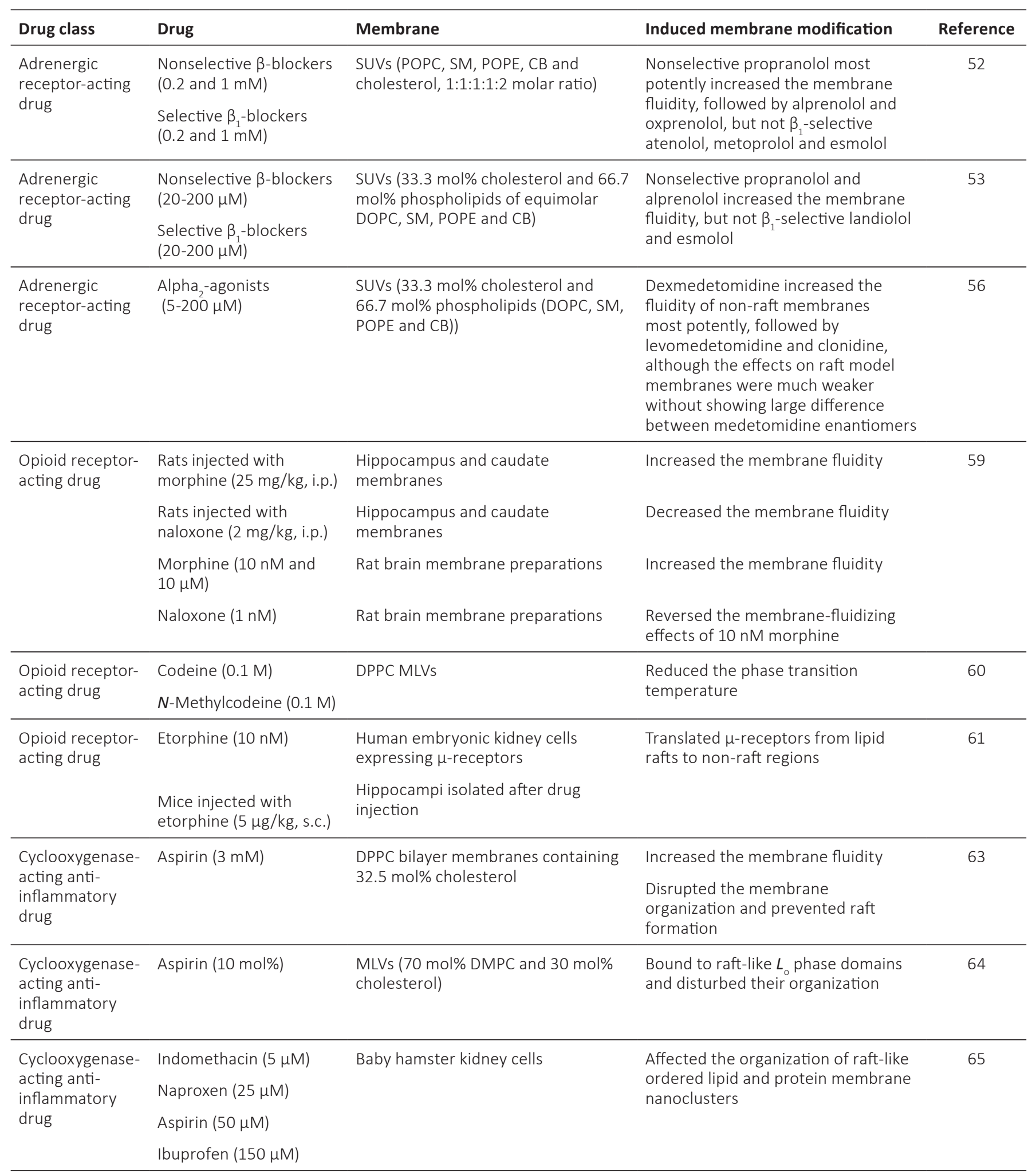

$\mathrm{CB}=$ cerebroside; $\mathrm{DMPC}=1$,2-dimyristoylphosphatidylcholine; DOPC = 1,2-dioleoylphosphatidylcholine; DPPC = 1,2-dipalmitoylphosphatidylcholine; MLV = multilamellar vesicle; POPC = 1-palmitoyl-2-oleoylphosphatidylcholine; POPE = 1-palmitoyl-2-oleoylphosphatidylethanolamine; SM = sphingomyelin; SUV = small unilamellar vesicle. 
The mechanistic relevance of lipid rafts to the enantioselective effects of $\alpha_{2}$-agonists is inconclusive as Morris et al reported that $\alpha_{1}$-adrenergic receptors, but not $\alpha_{2}$-adrenergic receptors, occupy membrane lipid rafts (57).

\section{Opioid analgesics}

Morphine and its related drugs act on inhibitory opioid receptors of $\mu, \mathrm{k}$ and $\delta$ subtypes expressed in nociceptive neuronal circuits. Mu-receptors responsible for the effects of opioid analgesics and antagonists are located within lipid raft/caveola membrane domains (58).

Heron et al performed in vivo experiments to inject rats with opioids intraperitoneally and in vitro experiments to subject membranes prepared from rat brains to the reaction with opioids, followed by FP measurements (59). Morphine increased the fluidity of hippocampus and caudate membranes from rats injected at $25 \mathrm{mg} / \mathrm{kg}$ (i.p.) and the fluidity of the membrane preparations at $10 \mathrm{nM}$ and $10 \mu \mathrm{M}$. In contrast, opioid antagonist naloxone decreased the membrane fluidity of the same brain regions at $2 \mathrm{mg} / \mathrm{kg}$ (i.p.) and reversed the in vitro membrane-fluidizing effect of $10 \mathrm{nM}$ morphine at $1 \mathrm{nM}$. Budai et al evaluated the effects of different opioids on DPPC multilamellar vesicles (MLVs) by DSC and electron paramagnetic resonance (EPR) spectroscopy (60). Codeine and $\mathrm{N}$-methylcodeine reduced the phase transition temperature of DPPC membranes at $0.1 \mathrm{M}$. Zheng et al treated HEK (human embryonic kidney) 293 cells expressing $\mu$-receptors with or subcutaneously injected mice with opioid agonists (61). SDGC cell fractions and hippocampus isolates demonstrated that etorphine of $10 \mathrm{nM}$ and $5 \mu \mathrm{g} / \mathrm{kg}$ (s.c.) translocate $\mu$-receptors from lipid rafts to non-raft regions as well as cholesterol-depleting MBC.

\section{Anti-inflammatory drugs}

Non-steroidal anti-inflammatory drugs are considered to exert therapeutic and adverse effects by inhibiting cyclooxygenase (COX)-2 and COX-1, respectively. COX-2 is localized in lipid raft/caveola membrane domains and associated with caveolin-1 (62).

Alsop et al studied the effects of aspirin on different DPPC/cholesterol bilayer membrane systems by LangmuirBlodgett, DSC and ND experiments (63). Aspirin (3 mM) increased the membrane fluidity of DPPC membranes containing $32.5 \mathrm{~mol} \%$ cholesterol, disrupted the membrane organization and prevented the formation of $L_{0}$ phase lipid rafts. In the following neutron scattering experiments and molecular dynamics simulations, they prepared MLVs with 70 mol\% 1,2-dimyristoylphosphatidylcholine (DMPC) and $30 \mathrm{~mol} \%$ cholesterol to study the membrane effect of aspirin (64). Aspirin bound to raft-like $L_{0}$ phase domains and disrupted their organization at $10 \mathrm{~mol} \%$. Zhou et al reported that $5 \mu \mathrm{M}$ indomethacin, $25 \mu \mathrm{M}$ naproxen, $50 \mu \mathrm{M}$ aspirin and $150 \mu \mathrm{M}$ ibuprofen acted on BHK (baby hamster kidney) cells to affect the organization of raft-like ordered lipid and protein membrane nanoclusters by interacting with plasma membranes (65).

\section{Anticancer drugs}

In addition to conventional mechanistic effects, anticancer drugs exhibit apoptosis-inducing activity. Lipid rafts contribute to induction of the apoptosis selective for cancer cells (66). Alkylphospholipids, platinum(II) complex and antibiotics are presumed to act on lipid rafts as a membrane gateway to induce apoptosis (67). Alves et al recently published an excellent review on the biophysics of cancer cells and the relevance of drug and membrane interaction to cancer therapy (68). Results of the literature search on the interaction of anticancer drugs with membrane lipid rafts and membranes are shown in Table IV.

\section{Alkylphospholipids}

Ausili et al treated MLVs prepared with POPC, SM and cholesterol (1:1:1 molar ratio) with edelfosine at 10-20 mol\% relative to membrane lipids, followed by DSC, XD and NMR analysis (69). Edelfosine altered the raft organization and induced the appearance of a sharp phase transition at $20 \mathrm{~mol} \%$, suggesting a fluidity increase in membrane lipid rafts. When incubating with human acute T-cell leukemia (Jurkat T) cells, edelfosine colocalized in lipid rafts at concentrations higher than 20 mol\%. 10-(Octyloxy) decyl-2-(trimethylammonium) ethyl phosphate (ODPC) with the cytotoxic activity against cancer cell lines inhibits the proliferation of leukemia cells by inducing apoptosis. Gomide et al prepared giant unilamellar vesicles (GUVs) with DOPC, SM and cholesterol (1:1:1 molar ratio) to examine the effects of perifosine and ODPC on lipid rafts (70). In fluorescence microscopic observations, perifosine and ODPC disrupted membrane raft domains in GUVs so that the domains disappeared in less than $1 \mathrm{~min}$ after treatment at 100 $\mu \mathrm{M}$. Castro et al treated MLVs or unilamellar vesicles (ULVs) prepared with POPC, $N$-palmitoyl-SM and cholesterol (1:1:1 molar ratio) with anticancer alkylphospholipids, followed by FA measurements (71). Edelfosine and miltefosine were demonstrated to increase the fluidity of raft model membranes at 5-10 mol\% relative to membrane lipids. Wnętrzak et al studied the effects of synthetic phospholipid analog erucylphosphocholine on raft-mimic Langmuir monolayers composed of SM and cholesterol (2:1 molar ratio) (72). Erucylphosphocholine increased the membrane raft fluidity at higher than $0.3 \mathrm{~mol} \%$ relative to membrane lipids and weakened the interaction between cholesterol and SM. In a thermodynamic study using the same Langmuir monolayers, anticancer 2-hydroxyoleic acid increased the membrane fluidity of raft-mimic monolayers at higher than 0.1 mol\% relative to membrane lipids (73).

\section{Cisplatin}

Cisplatin acts on plasma membranes to trigger the Fas death receptor pathway at a membrane level (74). Lacour et al treated human colon carcinoma (HT29) cells $\left(7 \times 10^{5}\right.$ cells) with cisplatin at $5 \mu \mathrm{g} / \mathrm{mL}$ for $0.25-4$ hours (75). The cells were subjected to 12-DSA (12-doxylstearic acid) spin labeling followed by EPR spectroscopic analysis or cell lysis with Triton X-100 followed by SDGC fractionation and immunoblot 
TABLE IV - Interaction of anticancer drugs with lipid raft membrane domains and membranes

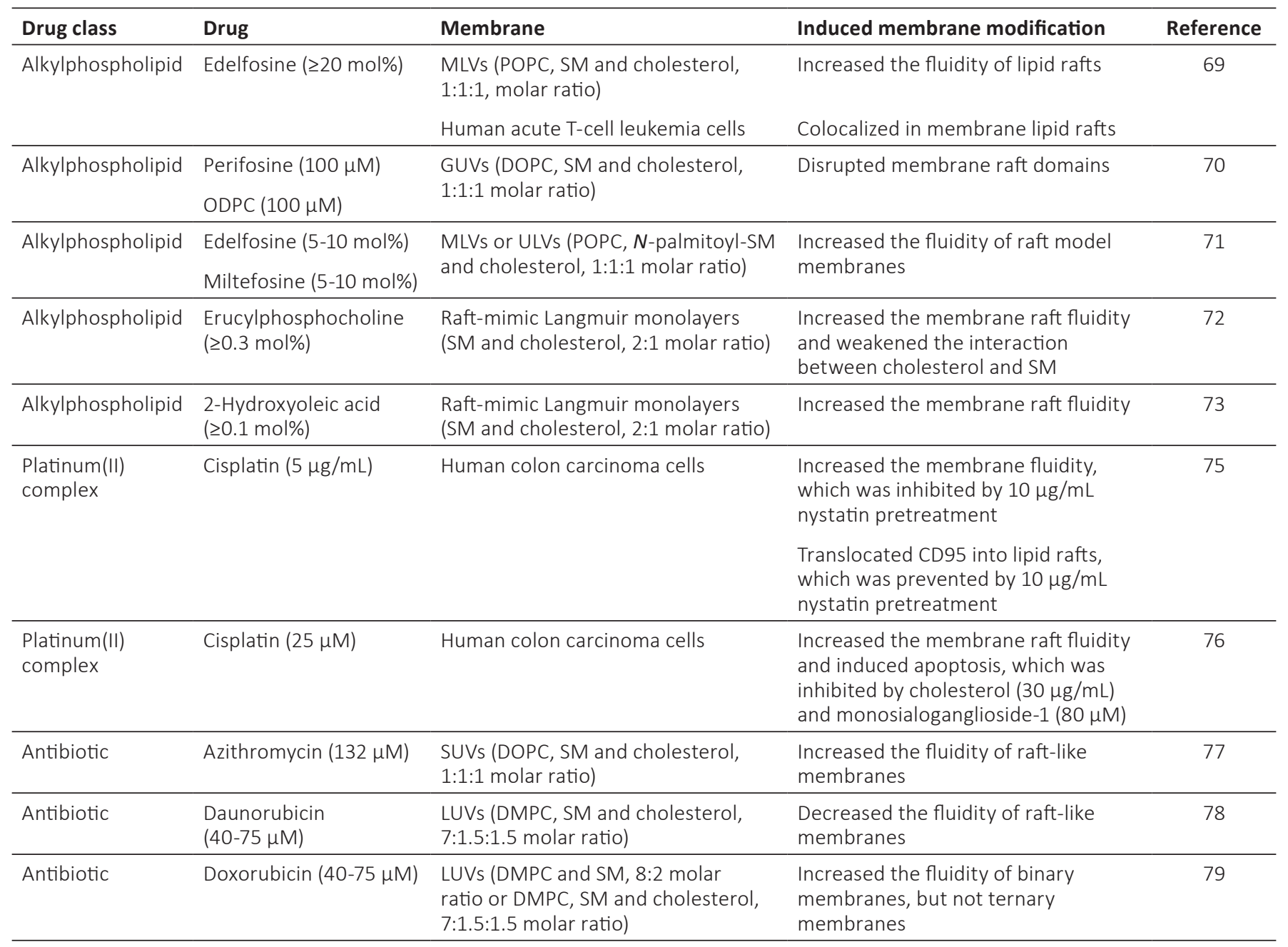

$\mathrm{DMPC}=1,2$-dimyristoylphosphatidylcholine; DOPC = 1,2-dioleoylphosphatidylcholine; GUV = giant unilamellar vesicle; LUV = large unilamellar vesicle; MLV = multilamellar vesicle; ODPC = 10-(octyloxy) decyl-2-(trimethylammonium) ethyl phosphate; POPC = 1-palmitoyl-2-oleoylphosphatidylcholine; SM = sphingomyelin; SUV = small unilamellar vesicle; ULV = unilamellar vesicle.

analysis. Cisplatin increased the fluidity of plasma membranes as soon as 0.25 hours after the treatment, although its membrane effect was inhibited by pretreating with cholesterol sequestering nystatin at $10 \mu \mathrm{g} / \mathrm{mL}$. The cell exposure to cisplatin for 4 hours induced the translocation of CD95 (cluster of differentiation 95 known as Fas receptor) into lipid rafts, which was prevented by nystatin pretreated at $10 \mu \mathrm{g} /$ $\mathrm{mL}$. Rebillard et al treated human colon carcinoma (HT29) cells growing in the exponential phase with cisplatin at $25 \mu \mathrm{M}$ for 1-72 hours (76). They isolated lipid rafts by SDGC and performed EPR spectroscopic analysis after 12-DSA spin labeling. Cisplatin treatment for 1 hour increased membrane raft fluidity and that for 72 hours induced apoptosis. Such effects were inhibited by membrane-stabilizing cholesterol (30 $\mu \mathrm{g} / \mathrm{mL}$ ) and monosialoganglioside-1 (80 $\mu \mathrm{M})$.

\section{Anticancer antibiotics}

Berquand et al treated SUVs prepared with DOPC, SM and cholesterol (1:1:1 molar ratio) with macrolide antibiotic azithromycin (77). FP analysis revealed that azithromycin increases the fluidity of a hydrophobic region of raft-like membranes at $132 \mu \mathrm{M}$. In FA experiments of Alves et al (78), anthracycline antibiotic daunorubicin (40-75 $\mu \mathrm{M})$ decreased the fluidity of raft-like membranes of LUVs prepared with DMPC, SM and cholesterol (7:1.5:1.5 molar ratio), while this antibiotic was more effective in decreasing the membrane fluidity of LUVs prepared without cholesterol. Alves et al also investigated the effects of doxorubicin on LUVs prepared with DMPC and SM (8:2 molar ratio) or with DMPC, SM and cholesterol (7:1.5:1.5 molar ratio) by measuring FA (79). Doxorubicin increased the fluidity of binary membranes at $40-75 \mu \mathrm{M}$, but not raft-like ternary membranes containing cholesterol.

\section{Phytochemicals}

A variety of phytochemicals (bioactive components in plants) such as flavonoids exhibit a broad spectrum of pharmacological activity including antioxidant, antitumor, 
anti-inflammatory, analgesic, antimicrobial, cardioprotective, anti-allergic and antiplatelet ones. Many of them with the amphiphilic structure share the property to interact with artificial and biological membranes. The membrane interactivity of phytochemicals was recently reviewed by Tsuchiya
(80), especially the interaction of flavonoids with lipid rafts by Tarahovsky et al (81) and their induced changes in membrane fluidity by Selvaraj et al (82). Results of the literature search on the interaction of phytochemicals with membrane lipid rafts and membranes are shown in Table V.

TABLE V - Interaction of phytochemicals with lipid raft membrane domains and membranes

\begin{tabular}{|c|c|c|c|c|}
\hline Drug class & Drug & Membrane & Induced membrane modification & Reference \\
\hline \multirow[t]{3}{*}{ Flavonoid } & Quercetin $(10 \mu \mathrm{M})$ & \multirow{3}{*}{$\begin{array}{l}\text { SUVS (phospholipids (POPC and } \\
\text { SM) and cholesterol by varying the } \\
\text { composition } 55-80 \text { mol\% and } 20-45 \\
\text { mol\%) }\end{array}$} & \multirow{3}{*}{$\begin{array}{l}\text { Quercetin decreased the } \\
\text { membrane fluidity most potently, } \\
\text { followed by cyanidin and EGCG }\end{array}$} & \multirow[t]{3}{*}{84} \\
\hline & EGCG $(10 \mu \mathrm{M})$ & & & \\
\hline & Cyanidin $(10 \mu \mathrm{M})$ & & & \\
\hline Flavonoid & Quercetin $(30 \mu \mathrm{M})$ & $\begin{array}{l}\text { Human colon cancer cells } \\
\text { (HT-29, SW-620 and Caco-2) }\end{array}$ & $\begin{array}{l}\text { Enhanced TRAIL efficacy to induce } \\
\text { apoptosis by accumulating death } \\
\text { receptors in membrane lipid rafts }\end{array}$ & 85 \\
\hline \multirow[t]{2}{*}{ Flavonoid } & Quercetin (10 and $100 \mu \mathrm{M})$ & \multirow[t]{2}{*}{ Mouse macrophages } & \multirow{2}{*}{$\begin{array}{l}\text { Suppressed the accumulation } \\
\text { of lipid rafts to inhibit TNF- } \alpha \\
\text { production }\end{array}$} & \multirow[t]{2}{*}{86} \\
\hline & Luteolin (10 and $100 \mu \mathrm{M})$ & & & \\
\hline Flavonoid & Quercetin $(2-16 \mu \mathrm{M})$ & $\begin{array}{l}\text { SUVs (DMPC plus } 20 \text { or } 33 \text { mol\% } \\
\text { cholesterol) }\end{array}$ & $\begin{array}{l}\text { Increased the fluidity of raft model } \\
\text { membranes }\end{array}$ & 87 \\
\hline Flavonoid & EGCG $(5-100 \mu \mathrm{M})$ & $\begin{array}{l}\text { SUVs ( } 5 \text { mol\% cholesterol and } 95 \\
\text { mol\% POPC or DOPC) }\end{array}$ & $\begin{array}{l}\text { Decreased the fluidity of binary } \\
\text { membranes }\end{array}$ & 88 \\
\hline Flavonoid & EGCG $(5-20 \mu \mathrm{g} / \mathrm{mL})$ & Human colon carcinoma cells & $\begin{array}{l}\text { Reduced the membrane resistance } \\
\text { to Triton X-100 by decreasing } \\
\text { ordered membrane domains }\end{array}$ & 89 \\
\hline Flavonoid & EGCG $(5 \mu \mathrm{M})$ & Human prostate cancer cells & $\begin{array}{l}\text { Inhibited DilC }{ }_{16} \text { accumulation } \\
\text { in lipid ordered domains and } \\
\text { disrupted lipid rafts }\end{array}$ & 90 \\
\hline Flavonoid & EGCG $(5-20 \mu \mathrm{M})$ & Human multiple myeloma cells & $\begin{array}{l}\text { Induced lipid raft clustering and } \\
\text { apoptotic cell death }\end{array}$ & 91 \\
\hline Flavonoid & $\begin{array}{l}\text { Dimeric procyanidin } \\
(0.05-1 \mu \mathrm{g} / \mathrm{mL})\end{array}$ & Human acute T-cell leukemia cells & Increased the membrane fluidity & 92 \\
\hline \multirow[t]{2}{*}{ Flavonoid } & \multirow[t]{2}{*}{$\begin{array}{l}\text { Hexameric procyanidin } \\
(10 \mu \mathrm{M})\end{array}$} & \multirow[t]{2}{*}{ Human colon cancer cells } & $\begin{array}{l}\text { Decreased the membrane fluidity, } \\
\text { although the membrane interactivity } \\
\text { was lost by MBC ( } 2.5 \mathrm{mM})\end{array}$ & \multirow[t]{2}{*}{93} \\
\hline & & & $\begin{array}{l}\text { Prevented the lipid raft disruption } \\
\text { induced by } \mathrm{MBC} \text { or deoxycholate }\end{array}$ & \\
\hline Stilbenoid & Resveratrol $(10-80 \mu \mathrm{M})$ & $\begin{array}{l}\text { LUVs (egg phosphatidylcholine, SM } \\
\text { and cholesterol, 1:1:1 molar ratio) }\end{array}$ & $\begin{array}{l}\text { Formed the ordered membrane } \\
\text { domains and enhanced the } \\
\text { membrane resistance to Triton X-100 }\end{array}$ & 94 \\
\hline \multirow[t]{2}{*}{ Anthraquinonoid } & Emodin (1-5 mol\%) & \multirow[t]{2}{*}{ MLVs composed of DMPC } & \multirow{2}{*}{$\begin{array}{l}\text { Reduced the phase transition } \\
\text { temperature }\end{array}$} & \multirow[t]{2}{*}{95} \\
\hline & Aloin (1-5 mol\%) & & & \\
\hline Anthraquinonoid & Emodin $(10-50 \mu \mathrm{g} / \mathrm{mL})$ & $\begin{array}{l}\text { Human umbilical vein endothelial } \\
\text { cells }\end{array}$ & Disrupted lipid rafts & 96 \\
\hline \multirow[t]{2}{*}{ Terpenoid } & \multirow{2}{*}{$\begin{array}{l}\text { Ginsenosides Rb2, Rc, Rd, } \\
\text { Re, Rf, Rg1, Rg2 and Rh2 } \\
(50 \mu \mathrm{M})\end{array}$} & \multirow[t]{2}{*}{ HeLa cells } & Increased the membrane fluidity & \multirow[t]{2}{*}{98} \\
\hline & & & $\begin{array}{l}\text { Reduced the raft-marker protein } \\
\text { concentration in lipid rafts }\end{array}$ & \\
\hline Terpenoid & Saikosaponin A (3-12 $\mu \mathrm{M})$ & Mouse macrophages & $\begin{array}{l}\text { Inhibited LPS-induced cytokine } \\
\text { expression and Toll-like receptor } \\
\text { localization in lipid rafts, and reduced } \\
\text { membrane cholesterol levels }\end{array}$ & 99 \\
\hline
\end{tabular}

DMPC = 1,2-dimyristoylphosphatidylcholine; $\mathrm{DOPC}=1,2$-dioleoylphosphatidylcholine; $E G C G=(-)$-epigallocatechin-3-gallate; $L$ PS = lipopolysaccharide; $\mathrm{LUV}=$ large unilamellar vesicle; $\mathrm{MBC}=$ methyl- $\beta$-cyclodextrin; $\mathrm{MLV}=$ multilamellar vesicle; $\mathrm{POPC}=1$-palmitoyl-2-oleoylphosphatidylcholine; $\mathrm{SM}=$ sphingomyelin; SUV = small unilamellar vesicle; TNF = tumor necrosis factor; TRAIL = TNF-related apoptosis-inducing ligand. 


\section{Flavonoids}

Considering the distribution and accumulation in lipid bilayers, representative flavonoid quercetin and (-)-epigallocatechin-3-gallate (EGCG) possibly alter membrane fluidity and order, making or breaking raft-like domains (83). Tsuchiya and Mizogami compared the effects of different flavonoids on SUVs that were prepared with phospholipids (POPC and $\mathrm{SM}$ ) and cholesterol by varying their compositions 55-80 mol\% and 20-45 mol\%, respectively (84). FP data indicated that quercetin interacts preferentially with the hydrophobic region of membranes to decrease the fluidity at $10 \mu \mathrm{M}$ most potently, followed by cyanidin and EGCG. Psahoulia et al investigated the mechanism underlying an apoptosisenhancing effect of quercetin by treating human colon cancer cells (HT-29, SW-620 and Caco-2) with quercetin at $30 \mu \mathrm{M}$ (85). While tumor necrosis factor (TNF)-related apoptosisinducing ligand (TRAIL) contributes to apoptosis induction, quercetin enhanced the TRAIL efficacy to induce apoptosis by accumulating death receptors in membrane lipid rafts. In a cell culture study of Kaneko et al, quercetin and luteolin suppressed the accumulation of lipid rafts at 10 and $100 \mu \mathrm{M}$ to inhibit TNF- $\alpha$ production in mouse macrophages (86). They also suggested that these flavonoids change membrane fluidity. Ionescu et al prepared SUVs with DMPC plus 20 or $33 \mathrm{~mol} \%$ cholesterol to form the $L_{0}$ phase and examine the membrane effect of quercetin (87). FP measurements showed that quercetin increases the fluidity of raft model membranes at 2-16 $\mu \mathrm{M}$.

Tsuchiya treated SUVs consisting of $5 \mathrm{~mol} \%$ cholesterol and 95 mol\% POPC or DOPC with several catechins, followed by FP measurements (88). Of the tested catechins, EGCG most potently interacted with binary membranes to decrease their fluidity at 5-100 $\mu \mathrm{M}$. Adachi et al stained human colon carcinoma (HT29) cells with fluorescent DilC ${ }_{16}$ (1,1'-dihexadecyl$3,3,3^{\prime}, 3^{\prime}$-tetramethylindocarbocyanine perchlorate) that is preferentially incorporated into the ordered membranes, and then treated the cells with EGCG at $5-20 \mu \mathrm{g} / \mathrm{mL}$ to analyze its membrane effects by fluorescent confocal microscopy (89). EGCG reduced the membrane resistance to Triton $\mathrm{X}-100$ at as little as $5 \mu \mathrm{g} / \mathrm{mL}$, possibly by decreasing the content of ordered membrane domains. Duhon et al exposed human prostate cancer (DU145) cells to DilC ${ }_{16}$ in the presence or absence of $5 \mu \mathrm{M}$ EGCG, followed by fluorescence microscopic analysis (90). EGCG inhibited the accumulation of DilC ${ }_{16}$ in lipid-ordered domains and disrupted lipid rafts. Tsukamoto et al treated human multiple myeloma (U266) cells with EGCG at 5-20 $\mu \mathrm{M}$ for 3 hours and at $10 \mu \mathrm{M}$ for 1-3 hours (91). Fluorescence resonance energy transfer and fluorescence microscopic assays indicated that EGCG dose- and time-dependently induces lipid raft clustering and apoptotic cell death.

Procyanidins contained in fruits and vegetables are oligomeric flavonoids with the anticancer activity. Verstraeten et al treated human acute T-cell leukemia (Jurkat T) cells $\left(6 \times 10^{4}\right.$ cells) with cocoa procyanidins and measured FP (92). Dimeric procyanidin increased the fluidity of plasma membranes in a concentration-dependent manner at 0.05-1 $\mathrm{\mu g} /$ $\mathrm{mL}$. In the following experiment, they incubated human colon cancer (Caco-2) cells with $10 \mu \mathrm{M}$ hexameric procyanidin in the absence or presence of $2.5 \mathrm{mM} \mathrm{MBC} \mathrm{(93).} \mathrm{In} \mathrm{contrast}$ to dimeric procyanidin, hexameric procyanidin decreased the fluidity of plasma membranes, although its membrane interactivity was lost by cholesterol-depleting MBC. This procyanidin also prevented lipid raft disruption induced by $\mathrm{MBC}$ or deoxycholate (cholesterol depletion/redistribution).

\section{Stilbenoids}

Resveratrol present in grape skins and seeds has anticancer, antioxidant and cardioprotective property. Neves et al treated LUVs prepared with egg phosphatidylcholine, SM and cholesterol (1:1:1 molar ratio) with 10-80 $\mu \mathrm{M}$ resveratrol to investigate the effects on raft model membranes by three different methods (94). Resveratrol induced the phase separation and formed the ordered membrane domains at concentrations higher than $10 \mu \mathrm{M}$. Such effects were more pronounced in the presence of cholesterol and SM. Resveratrol was also effective at $80 \mu \mathrm{M}$ in enhancing the membrane resistance to Triton $\mathrm{X}-100$.

\section{Anthraquinonoids}

Pharmacological effects of aloe are attributed to anthraquinonoid component emodin and aloin (barbaloin). DSC experiments of Alves et al demonstrated that emodin interacts with MLVs composed of DMPC to reduce the phase transition temperature at 1-5 mol\% more potently than aloin (95). Meng et al investigated the mechanism underlying a vascular anti-inflammatory effect of aloe by treating human umbilical vein endothelial cells grown to approximately $90 \%$ confluence with emodin (96). Emodin $(10-50 \mu \mathrm{g} / \mathrm{mL})$ inhibited the expression of proinflammatory cytokines and chemokines induced by $0.1 \mu \mathrm{g} / \mathrm{mL}$ lipopolysaccharide (LPS). Similar to cholesterol-depleting MBC $(5-12.5 \mathrm{mM})$, emodin $(10-50 \mu \mathrm{g} / \mathrm{mL})$ disrupted lipid rafts that are relevant to the cell activation by LPS. Lipid raft disruption associated with integrin signaling pathway is also responsible for the inhibitory effects of emodin on tumor cell adhesion and spreading (97).

\section{Terpenoids}

Triterpenoid glycosides from Panax ginseng and triterpenoid saponin derivatives from Radix bupleuri have antiinflammatory and anticancer activity. Yi et al treated HeLa cells with different ginsenosides at $50 \mu \mathrm{M}$ and stained the cells with carboxy Laurdan, followed by fluorescence microscopy and generalized polarization imaging (98). Ginsenosides Rb2, Rc, $\mathrm{Rd}, \mathrm{Re}, \mathrm{Rf}, \mathrm{Rg} 1, \mathrm{Rg} 2$ and Rh2 increased the fluidity of plasma membranes as well as cholesterol-depleting MBC (10 mM). When fractionating the HeLa cells by SDGC, ginsenoside Rh2 and $\mathrm{MBC}$ reduced the concentration of raft-marker proteins in the raft fraction, indicating that they disrupt lipid rafts. These effects of ginsenoside Rh2 were reversed by cholesterol overloading $(20 \mu \mathrm{g} / \mathrm{mL})$. In a cell culture study of Wei et al (99), 3-12 $\mu \mathrm{M}$ saikosaponin A inhibited the expression of cytokines in primary mouse macrophages stimulated by $0.1 \mu \mathrm{g} / \mathrm{mL}$ LPS. Such inhibitory effects were attenuated by replenishment of $84 \mu \mathrm{g} / \mathrm{mL}$ cholesterol, while 3-12 $\mu \mathrm{M}$ saikosaponin A reduced cholesterol levels in macrophage membranes. Saikosaponin A (3-12 $\mu \mathrm{M})$ and MBC (10 mM) also inhibited the LPS-induced 
localization in lipid rafts of Toll-like receptors that play a crucial role in the innate immune system.

\section{Conclusions}

Results of the literature search indicate that different classes of drugs interact with raft model membranes and cellular membrane lipid rafts in addition to interacting directly with membrane receptors, ion channels and enzymes. They could physicochemically modify membrane lipid rafts to be a platform for functional proteins and the membranes surrounding such raft domains, affecting the organizational integrity of lipid rafts with the subsequent alteration of receptor, channel and enzyme activity, thereby producing pharmacological effects. With respect to the induced membrane modification, raft-acting drugs are characterized as ones to decrease membrane fluidity, induce $L_{0}$ phase or order plasma membranes, leading to lipid raft formation; and ones to increase membrane fluidity, induce $L_{d}$ phase or reduce phase transition temperature, leading to lipid raft disruption. Targeting lipid raft membrane domains would open a new way for drug design and development.

Given the critical role of lipid rafts/caveolae in cellular signal transduction, odontology may be the promising field to which a raft-targeting concept is applied. Anticancer drugs interact with membrane lipid rafts to affect their physicochemical property and organizational integrity in association with apoptosis induction. Lipid raft membrane domains are responsible for cancer cell adhesion and migration, and the levels of cholesterol-rich lipid rafts are elevated in cancer cells compared with normal counterparts $(100,101)$. While phytochemicals interact with membrane lipid rafts and regulate raft formation $(83,85)$, such interactivity is responsible for their diverse bioactivities including apoptosis induction. Among raft-targeting compounds, alkylphospholipids and flavonoids could be a novel type of anticancer drug.

Since an outbreak of atypical pneumonia was first reported in Wuhan (China) in December 2019, novel coronavirus or severe acute respiratory syndrome coronavirus 2 (SARS-CoV-2) infections have spread worldwide, causing a global pandemic of coronavirus disease 2019 (COVID-19). SARS-CoV-2 spike proteins have a strong binding affinity to human angiotensin-converting enzyme 2 (ACE2) (102). Host cell ACE2 receptors, which are a cell-specific target of and responsible for the cellular entry of SARS-CoV-2, are localized in lipid rafts (103). Cholesterol-rich membrane domains are essential for the spike proteins to interact with ACE2 receptors efficiently (104) and cellular cholesterol levels are closely associated with COVID-19 lethality (105). Agents that specifically disrupt ACE2-localizing lipid rafts and deplete raft cholesterol may be a drug to reduce SARS-CoV-2 infectivity and COVID-19 severity.

\section{Abbreviations}

$L_{\mathrm{o}}$, liquid-ordered; $L_{\mathrm{d}}$, liquid-disordered; POPC, 1-palmitoyl-2-oleoylphosphatidylcholine; SM, sphingomyelin; SDGC, sucrose density gradient centrifugation; $M B C$, methyl- $\beta$ cyclodextrin; FP, fluorescence polarization; $F A$, fluorescence anisotropy; DSC, differential scanning calorimetry; NMR, nuclear magnetic resonance; ND, neutron diffraction; $X D, X$ ray diffraction; $\mathrm{GABA}_{\mathrm{A}^{\prime}}, \gamma$-aminobutyric acid type $A$; NMDA, $\mathrm{N}$-methyl-D-aspartate; POPE, 1-palmitoyl-2-oleoylphosphatidylethanolamine; POPS, 1-palmitoyl-2-oleoylphosphatidylserine; GPMV, giant plasma membrane vesicle; LUV, large unilamellar vesicle; DPPC, 1,2-dipalmitoylphosphatidylcholine; DLPC, 1,2-dilauroylphosphatidylcholine; MAC, minimum alveolar concentration; DOPC, 1,2-dioleoylphosphatidylcholine; Nav, voltage-gated sodium; SUV, small unilamellar vesicle; $\mathrm{CB}$, cerebroside; POPI, 1-palmitoyl-2-oleoylphosphatidylinositol; MLV, multilamellar vesicle; EPR, electron paramagnetic resonance; COX, cyclooxygenase; DMPC, 1,2-dimyristoylphosphatidylcholine; ODPC, 10-(octyloxy) decyl-2-(trimethylammonium) ethyl phosphate; GUV, giant unilamellar vesicle; ULV, unilamellar vesicle; EGCG, (-)-epigallocatechin-3-gallate; TNF, tumor necrosis factor; TRAIL, TNF-related apoptosis-inducing ligand; LPS, lipopolysaccharide; SARS-CoV-2, severe acute respiratory syndrome coronavirus 2; COVID-19, coronavirus disease 2019; ACE2, angiotensin-converting enzyme 2.

\section{Author contributions}

HT designed and conducted the present study and prepared the first draft of the manuscript. HT and MM did literature search, information analysis and manuscript preparation. Both authors reviewed and approved the final manuscript.

\section{Disclosures}

Conflict of interest: Authors disclose no potential conflicts of interest.

Financial support: This study was supported by JSPS KAKENHI grant number 20K10152 and JSPS KAKENHI grant number 17K11924.

\section{References}

1. Kusumi A, Fujiwara TK, Chadda R, et al. Dynamic organizing principles of the plasma membrane that regulate signal transduction: commemorating the fortieth anniversary of Singer and Nicolson's fluid-mosaic model. Annu Rev Cell Dev Biol. 2012;28(1):215-250. CrossRef Medline

2. Pike LJ. Rafts defined: a report on the Keystone Symposium on Lipid Rafts and Cell Function. J Lipid Res. 2006;47(7):1597-1598. CrossRef Medline

3. Hanzal-Bayer MF, Hancock JF. Lipid rafts and membrane traffic. FEBS Lett. 2007;581(11):2098-2104. CrossRef Medline

4. McMullen T, Lewis R, McElhany R. Cholesterol-phospholipid interactions, the liquid-ordered phase and lipid rafts in model and biological membranes. Curr Opin Colloid Interface Sci. 2004;8(6):459-468. CrossRef

5. Simons K, Toomre D. Lipid rafts and signal transduction. Nat Rev Mol Cell Biol. 2000;1(1):31-39. CrossRef Medline

6. Laude AJ, Prior IA. Plasma membrane microdomains: organization, function and trafficking. Mol Membr Biol. 2004;21(3):193205. CrossRef Medline

7. George KS, Wu S. Lipid raft: A floating island of death or survival. Toxicol Appl Pharmacol. 2012;259(3):311-319. CrossRef Medline

8. O'Connell KM, Martens JR, Tamkun MM. Localization of ion channels to lipid Raft domains within the cardiovascular system. Trends Cardiovasc Med. 2004;14(2):37-42. CrossRef Medline 
9. Maguy A, Hebert TE, Nattel S. Involvement of lipid rafts and caveolae in cardiac ion channel function. Cardiovasc Res. 2006;69(4):798-807. CrossRef Medline

10. Dalskov SM, Immerdal L, Niels-Christiansen LL, Hansen GH, Schousboe A, Danielsen EM. Lipid raft localization of GABA receptor and $\mathrm{Na}^{+}, \mathrm{K}^{+}$-ATPase in discrete microdomain clusters in rat cerebellar granule cells. Neurochem Int. 2005;46(6):489499. CrossRef Medline

11. Patel HH, Murray F, Insel PA. G-protein-coupled receptor-signaling components in membrane raft and caveolae microdomains. Handb Exp Pharmacol. 2008;186(186):167-184. CrossRef Medline

12. Xiang Y, Rybin VO, Steinberg SF, Kobilka B. Caveolar localization dictates physiologic signaling of $\beta_{2}$-adrenoceptors in neonatal cardiac myocytes. J Biol Chem. 2002;277(37):34280-34286. CrossRef Medline

13. Pottosin II, Valencia-Cruz G, Bonales-Alatorre E, Shabala SN, Dobrovinskaya OR. Methyl- $\beta$-cyclodextrin reversibly alters the gating of lipid rafts-associated Kv1.3 channels in Jurkat T lymphocytes. Pflugers Arch. 2007;454(2):235-244. CrossRef Medline

14. Levitt ES, Clark MJ, Jenkins PM, Martens JR, Traynor JR. Differential effect of membrane cholesterol removal on $\mu$ - and $\delta$-opioid receptors: a parallel comparison of acute and chronic signaling to adenylyl cyclase. J Biol Chem. 2009;284(33):2210822122. CrossRef Medline

15. Ding XQ, Fitzgerald JB, Matveev AV, McClellan ME, Elliott MH. Functional activity of photoreceptor cyclic nucleotide-gated channels is dependent on the integrity of cholesterol- and sphingolipid-enriched membrane domains. Biochemistry. 2008;47(12):3677-3687. CrossRef Medline

16. Gandhavadi M, Allende D, Vidal A, Simon SA, Mclntosh TJ. Structure, composition, and peptide binding properties of detergent soluble bilayers and detergent resistant rafts. Biophys J. 2002;82(3):1469-1482. CrossRef Medline

17. Koumanov KS, Tessier $C$, Momchilova AB, Rainteau D, Wolf $C$, Quinn PJ. Comparative lipid analysis and structure of detergentresistant membrane raft fractions isolated from human and ruminant erythrocytes. Arch Biochem Biophys. 2005;434(1): 150-158. CrossRef Medline

18. Holland GP, McIntyre SK, Alam TM. Distinguishing individual lipid headgroup mobility and phase transitions in raft-forming lipid mixtures with ${ }^{31}$ P MAS NMR. Biophys J. 2006;90(11):42484260. CrossRef Medline

19. Simons K, Ehehalt R. Cholesterol, lipid rafts, and disease. J Clin Invest. 2002;110(5):597-603. CrossRef Medline

20. Jacobson K, Mouritsen OG, Anderson RG. Lipid rafts: at a crossroad between cell biology and physics. Nat Cell Biol. 2007;9(1):7-14. CrossRef Medline

21. Boesze-Battaglia K. Isolation of membrane rafts and signaling complexes. Methods Mol Biol. 2006;332:169-179. CrossRef Medline

22. Loftsson T, Magnúsdóttir A, Másson M, Sigurjónsdóttir JF. Selfassociation and cyclodextrin solubilization of drugs. J Pharm Sci. 2002;91(11):2307-2316. CrossRef Medline

23. Mahammad S, Parmryd I. Cholesterol depletion using methyl$\beta$-cyclodextrin. Methods Mol Biol. 2015;1232:91-102. CrossRef Medline

24. Chau PL. New insights into the molecular mechanisms of general anaesthetics. Br J Pharmacol. 2010;161(2):288-307. CrossRef Medline

25. Olsen RW, Li GD. GABA receptors as molecular targets of general anesthetics: identification of binding sites provides clues to allosteric modulation. Can J Anaesth. 2011;58(2):206-215. CrossRef Medline

26. Yamakura T, Harris RA. Effects of gaseous anesthetics nitrous oxide and xenon on ligand-gated ion channels. Comparison with isoflurane and ethanol. Anesthesiology. 2000;93(4):10951101. CrossRef Medline

27. Daniell LC. Effect of anesthetic and convulsant barbiturates on $\mathrm{N}$-methyl- $D$-aspartate receptor-mediated calcium flux in brain membrane vesicles. Pharmacology. 1994;49(5):296-307. CrossRef Medline

28. Li X, Serwanski DR, Miralles CP, Bahr BA, De Blas AL. Two pools of Triton $X-100$-insoluble $\mathrm{GABA}_{A}$ receptors are present in the brain, one associated to lipid rafts and another one to the postsynaptic GABAergic complex. J Neurochem. 2007;102(4):13291345. CrossRef Medline

29. Parat MO. Could endothelial caveolae be the target of general anaesthetics? Br J Anaesth. 2006;96(5):547-550. CrossRef Medline

30. Tsuchiya H. Structure-specific membrane-fluidizing effect of propofol. Clin Exp Pharmacol Physiol. 2001;28(4):292-299. CrossRef Medline

31. Tsuchiya H, Ueno T, Tanaka T, Matsuura N, Mizogami M. Comparative study on determination of antioxidant and membrane activities of propofol and its related compounds. Eur J Pharm Sci. 2010;39(1-3):97-102. CrossRef Medline

32. Gray E, Karslake J, Machta BB, Veatch SL. Liquid general anesthetics lower critical temperatures in plasma membrane vesicles. Biophys J. 2013;105(12):2751-2759. CrossRef Medline

33. Grim KJ, Abcejo AJ, Barnes A, et al. Caveolae and propofol effects on airway smooth muscle. Br J Anaesth. 2012;109(3):444453. CrossRef Medline

34. Patel J, Chowdhury EA, Noorani B, Bickel U, Huang J. Isoflurane increases cell membrane fluidity significantly at clinical concentrations. Biochim Biophys Acta Biomembr. 2020;1862(2):183140. CrossRef Medline

35. Turkyilmaz S, Almeida PF, Regen SL. Effects of isoflurane, halothane, and chloroform on the interactions and lateral organization of lipids in the liquid-ordered phase. Langmuir. 2011;27(23):14380-14385. CrossRef Medline

36. Weinrich $M$, Nanda H, Worcester DL, Majkrzak CF, Maranville $\mathrm{BB}$, Bezrukov SM. Halothane changes the domain structure of a binary lipid membrane. Langmuir. 2012;28(10):4723-4728. CrossRef Medline

37. Weinrich M, Worcester DL. Xenon and other volatile anesthetics change domain structure in model lipid raft membranes. J Phys Chem B. 2013;117(50):16141-16147. CrossRef Medline

38. Sierra-Valdez FJ, Ruiz-Suárez JC, Delint-Ramirez I. Pentobarbital modifies the lipid raft-protein interaction: $A$ first clue about the anesthesia mechanism on NMDA and GABA receptors. Biochim Biophys Acta. 2016;1858(11):2603-2610. CrossRef Medline

39. Fozzard HA, Lee PJ, Lipkind GM. Mechanism of local anesthetic drug action on voltage-gated sodium channels. Curr Pharm Des. 2005;11(21):2671-2686. CrossRef Medline

40. Pristerá A, Okuse K. Building excitable membranes: lipid rafts and multiple controls on trafficking of electrogenic molecules. Neuroscientist. 2012;18(1):70-81. CrossRef Medline

41. Bao L. Trafficking regulates the subcellular distribution of voltage-gated sodium channels in primary sensory neurons. Mol Pain. 2015;11:61. CrossRef Medline

42. Pristerà $A$, Baker $M D$, Okuse K. Association between tetrodotoxin resistant channels and lipid rafts regulates sensory neuron excitability. PLoS One. 2012;7(8):e40079. CrossRef Medline

43. Kamata K, Manno S, Ozaki M, Takakuwa Y. Functional evidence for presence of lipid rafts in erythrocyte membranes: $\mathrm{Gs} \alpha$ in rafts is essential for signal transduction. Am J Hematol. 2008;83(5):371-375. CrossRef Medline

44. Bandeiras C, Serro AP, Luzyanin K, Fernandes A, Saramago B. Anesthetics interacting with lipid rafts. Eur J Pharm Sci. 2013;48(1-2):153-165. CrossRef Medline 
45. Yoshida K, Takashima A, Nishio I. Effect of dibucaine hydrochloride on raft-like lipid domains in model membrane system. MedChemComm. 2015;6(8):1444-1451. CrossRef

46. Sugahara K, Shimokawa N, Takagi M. Thermal stability of phaseseparated domains in multicomponent lipid membranes with local anesthetics. Membranes (Basel). 2017;7(3):33. CrossRef Medline

47. Kinoshita M, Chitose T, Matsumori N. Mechanism of local anesthetic-induced disruption of raft-like ordered membrane domains. Biochim Biophys Acta, Gen Subj. 2019;1863(9):13811389. CrossRef Medline

48. Groban L, Deal DD, Vernon JC, James RL, Butterworth J. Cardiac resuscitation after incremental overdosage with lidocaine, bupivacaine, levobupivacaine, and ropivacaine in anesthetized dogs. Anesth Analg. 2001;92(1):37-43. CrossRef Medline

49. Tsuchiya H, Ueno T, Mizogami M, Takakura K. Do local anesthetics interact preferentially with membrane lipid rafts? Comparative interactivities with raft-like membranes. J Anesth. 2010;24(4):639-642. CrossRef Medline

50. Tsuchiya H, Mizogami M. R(+)--, Rac-, and S(-)-bupivacaine stereostructure-specifically interact with membrane lipids at cardiotoxically relevant concentrations. Anesth Analg. 2012;114(2): 310-312. CrossRef Medline

51. Pontier SM, Percherancier Y, Galandrin S, Breit A, Galés C, Bouvier M. Cholesterol-dependent separation of the $\beta_{2}$-adrenergic receptor from its partners determines signaling efficacy: insight into nanoscale organization of signal transduction. J Biol Chem. 2008;283(36):24659-24672. CrossRef Medline

52. Mizogami M, Takakura K, Tsuchiya H. The interactivities with lipid membranes differentially characterize selective and nonselective $\beta_{1}$-blockers. Eur J Anaesthesiol. 2010;27(9):829-834. CrossRef Medline

53. Tsuchiya H, Mizogami M. Characteristic interactivity of landiolol, an ultra-short-acting highly selective $\beta_{1}$-blocker, with biomimetic membranes: comparisons with $\beta_{1}$-selective esmolol and non-selective propranolol and alprenolol. Front Pharmacol. 2013;4:150. CrossRef Medline

54. Prichard BN, Cruickshank JM, Graham BR. Beta-adrenergic blocking drugs in the treatment of hypertension. Blood Press. 2001;10(5-6):366-386. CrossRef Medline

55. Callera GE, Montezano AC, Yogi A, Tostes RC, Touyz RM. Vascular signaling through cholesterol-rich domains: implications in hypertension. Curr Opin Nephrol Hypertens. 2007;16(2):90104. CrossRef Medline

56. Mizogami $M$, Tsuchiya $H$. Membrane interactivity of anesthetic adjuvant dexmedetomidine discriminable from clonidine and enantiomeric levomedetomidine. J Adv Med Med Res. 2019;29:1-15. CrossRef

57. Morris DP, Lei B, Wu YX, Michelotti GA, Schwinn DA. The $\alpha_{1 a}$ adrenergic receptor occupies membrane rafts with its $G$ protein effectors but internalizes via clathrin-coated pits. J Biol Chem. 2008;283(5):2973-2985. CrossRef Medline

58. Huang $\mathrm{P}, \mathrm{Xu} \mathrm{W}$, Yoon $\mathrm{SI}$, et al. Agonist treatment did not affect association of mu opioid receptors with lipid rafts and cholesterol reduction had opposite effects on the receptor-mediated signaling in rat brain and CHO cells. Brain Res. 2007;1184:4656. CrossRef Medline

59. Heron DS, Shinitzky M, Zamir N, Samuel D. Adaptive modulations of brain membrane lipid fluidity in drug addiction and denervation supersensitivity. Biochem Pharmacol. 1982;31(14):2435-2438. CrossRef Medline

60. Budai M, Szabó Z, Szogyi M, Gróf P. Molecular interactions between DPPC and morphine derivatives: a DSC and EPR study. Int J Pharm. 2003;250:239-250. CrossRef

61. Zheng H, Chu J, Qiu Y, Loh HH, Law PY. Agonist-selective signaling is determined by the receptor location within the membrane domains. Proc Natl Acad Sci USA. 2008;105(27):9421-9426. CrossRef Medline

62. Liou JY, Deng WG, Gilroy DW, Shyue SK, Wu KK. Colocalization and interaction of cyclooxygenase-2 with caveolin-1 in human fibroblasts. J Biol Chem. 2001;276(37):34975-34982. CrossRef Medline

63. Alsop RJ, Toppozini L, Marquardt D, Kučerka N, Harroun TA, Rheinstädter MC. Aspirin inhibits formation of cholesterol rafts in fluid lipid membranes. Biochim Biophys Acta. 2015;1848(3):805-812. CrossRef Medline

64. Alsop RJ, Himbert S, Dhaliwal A, Schmalzl K, Rheinstädter MC. Aspirin locally disrupts the liquid-ordered phase. $R$ Soc Open Sci. 2018;5(2):171710. CrossRef Medline

65. Zhou Y, Cho KJ, Plowman SJ, Hancock JF. Nonsteroidal antiinflammatory drugs alter the spatiotemporal organization of Ras proteins on the plasma membrane. J Biol Chem. 2012;287(20):16586-16595. CrossRef Medline

66. Alves ACS, Dias RA, Kagami LP, et al. Beyond the "lock and key" paradigm: targeting lipid rafts to induce the selective apoptosis of cancer cells. Curr Med Chem. 2018;25(18):2082-2104. CrossRef Medline

67. van der Luit AH, Vink SR, Klarenbeek JB, et al. A new class of anticancer alkylphospholipids uses lipid rafts as membrane gateways to induce apoptosis in lymphoma cells. Mol Cancer Ther. 2007;6(8):2337-2345. CrossRef Medline

68. Alves AC, Ribeiro D, Nunes C, Reis S. Biophysics in cancer: the relevance of drug-membrane interaction studies. Biochim Biophys Acta. 2016;1858(9):2231-2244. CrossRef Medline

69. Ausili A, Torrecillas A, Aranda FJ, et al. Edelfosine is incorporated into rafts and alters their organization. J Phys Chem B. 2008;112(37):11643-11654. CrossRef Medline

70. Gomide $A B$, Thomé $C H$, dos Santos GA, et al. Disrupting membrane raft domains by alkylphospholipids. Biochim Biophys Acta. 2013;1828(5):1384-1389. CrossRef Medline

71. Castro BM, Fedorov A, Hornillos V, et al. Edelfosine and miltefosine effects on lipid raft properties: membrane biophysics in cell death by antitumor lipids. J Phys Chem B. 2013;117(26):79297940. CrossRef Medline

72. Wnętrzak A, Łątka K, Makyła-Juzak K, Zemla J, Dynarowicz-Łątka $P$. The influence of an antitumor lipid - erucylphosphocholine on artificial lipid raft system modeled as Langmuir monolayer. Mol Membr Biol. 2015;32(5-8):189-197. CrossRef Medline

73. Węder K, Mach M, Hąc-Wydro K, Wydro P. Studies on the interactions of anticancer drug - Minerval - with membrane lipids in binary and ternary Langmuir monolayers. Biochim Biophys Acta Biomembr. 2018;1860(11):2329-2336. CrossRef Medline

74. Rebillard A, Lagadic-Gossmann D, Dimanche-Boitrel MT. Cisplatin cytotoxicity: DNA and plasma membrane targets. Curr Med Chem. 2008;15(26):2656-2663. CrossRef Medline

75. Lacour S, Hammann A, Grazide S, et al. Cisplatin-induced CD95 redistribution into membrane lipid rafts of HT29 human colon cancer cells. Cancer Res. 2004;64(10):3593-3598. CrossRef Medline

76. Rebillard A, Tekpli X, Meurette O, et al. Cisplatin-induced apoptosis involves membrane fluidification via inhibition of NHE1 in human colon cancer cells. Cancer Res. 2007;67(16):7865-7874. CrossRef Medline

77. Berquand A, Fa N, Dufrêne YF, Mingeot-Leclercq MP. Interaction of the macrolide antibiotic azithromycin with lipid bilayers: effect on membrane organization, fluidity, and permeability. Pharm Res. 2005;22(3):465-475. CrossRef Medline

78. Alves AC, Ribeiro D, Horta M, Lima JLFC, Nunes C, Reis S. A biophysical approach to daunorubicin interaction with model membranes: relevance for the drug's biological activity. $J R$ Soc Interface. 2017;14(133):20170408. CrossRef Medline

79. Alves AC, Magarkar A, Horta M, et al. Influence of doxorubicin on model cell membrane properties: insights from in vitro and in silico studies. Sci Rep. 2017;7(1):6343. CrossRef Medline 
80. Tsuchiya H. Membrane interactions of phytochemicals as their molecular mechanism applicable to the discovery of drug leads from plants. Molecules. 2015;20(10):18923-18966. CrossRef Medline

81. Tarahovsky YS, Kim YA, Yagolnik EA, Muzafarov EN. Flavonoidmembrane interactions: involvement of flavonoid-metal complexes in raft signaling. Biochim Biophys Acta . 2014;1838(5):12351246. CrossRef Medline

82. Selvaraj S, Krishnaswamy S, Devashya V, Sethuraman S, Krishnan UM. Influence of membrane lipid composition on flavonoidmembrane interactions: implications on their biological activity. Prog Lipid Res. 2015;58:1-13. CrossRef Medline

83. Tarahovsky YS, Muzafarov EN, Kim YA. Rafts making and rafts braking: how plant flavonoids may control membrane heterogeneity. Mol Cell Biochem. 2008;314(1-2):65-71. CrossRef Medline

84. Tsuchiya H, Mizogami M. Plant components exhibit pharmacological activities and drug interactions by acting on lipid membranes. Pharmacog Commun. 2012;2:58-71. Online

85. Psahoulia FH, Drosopoulos KG, Doubravska L, Andera L, Pintzas A. Quercetin enhances TRAIL-mediated apoptosis in colon cancer cells by inducing the accumulation of death receptors in lipid rafts. Mol Cancer Ther. 2007;6(9):2591-2599. CrossRef Medline

86. Kaneko M, Takimoto $H$, Sugiyama T, Seki $Y$, Kawaguchi $K$, Kumazawa $Y$. Suppressive effects of the flavonoids quercetin and luteolin on the accumulation of lipid rafts after signal transduction via receptors. Immunopharmacol Immunotoxicol. 2008;30(4):867-882. CrossRef Medline

87. Ionescu D, Margină D, Ilie M, Iftime A, Ganea C. Quercetin and epigallocatechin-3-gallate effect on the anisotropy of model membranes with cholesterol. Food Chem Toxicol. 2013;61:94100. CrossRef Medline

88. Tsuchiya H. Stereospecificity in membrane effects of catechins. Chem Biol Interact. 2001;134(1):41-54. CrossRef Medline

89. Adachi $\mathrm{S}, \mathrm{Nagao} \mathrm{T}$, Ingolfsson $\mathrm{HI}$, et al. The inhibitory effect of (-)-epigallocatechin gallate on activation of the epidermal growth factor receptor is associated with altered lipid order in HT29 colon cancer cells. Cancer Res. 2007;67(13):6493-6501. CrossRef Medline

90. Duhon D, Bigelow RL, Coleman DT, et al. The polyphenol epigallocatechin-3-gallate affects lipid rafts to block activation of the c-Met receptor in prostate cancer cells. Mol Carcinog. 2010;49(8):739-749. CrossRef Medline

91. Tsukamoto S, Hirotsu K, Kumazoe M, et al. Green tea polyphenol EGCG induces lipid-raft clustering and apoptotic cell death by activating protein kinase $C \delta$ and acid sphingomyelinase through a $67 \mathrm{kDa}$ laminin receptor in multiple myeloma cells. Biochem J. 2012;443(2):525-534. CrossRef Medline

92. Verstraeten SV, Oteiza PI, Fraga CG. Membrane effects of cocoa procyanidins in liposomes and Jurkat T cells. Biol Res. 2004;37(2):293-300. CrossRef Medline
93. Verstraeten SV, Jaggers GK, Fraga CG, Oteiza PI. Procyanidins can interact with Caco-2 cell membrane lipid rafts: involvement of cholesterol. Biochim Biophys Acta. 2013;1828(11):26462653. CrossRef Medline

94. Neves AR, Nunes C, Reis S. Resveratrol induces ordered domains formation in biomembranes: implication for its pleiotropic action. Biochim Biophys Acta. 2016;1858(1):12-18. CrossRef Medline

95. Alves DS, Pérez-Fons L, Estepa A, Micol V. Membrane-related effects underlying the biological activity of the anthraquinones emodin and barbaloin. Biochem Pharmacol. 2004;68(3):549561. CrossRef Medline

96. Meng G, Liu Y, Lou C, Yang H. Emodin suppresses lipopolysaccharide-induced pro-inflammatory responses and NF-KB activation by disrupting lipid rafts in CD14-negative endothelial cells. Br J Pharmacol. 2010;161(7):1628-1644. CrossRef Medline

97. Huang $Q$, Shen HM, Shui G, Wenk MR, Ong CN. Emodin inhibits tumor cell adhesion through disruption of the membrane lipid raft-associated integrin signaling pathway. Cancer Res. 2006;66(11):5807-5815. CrossRef Medline

98. Yi JS, Choo HJ, Cho BR, et al. Ginsenoside Rh2 induces ligandindependent Fas activation via lipid raft disruption. Biochem Biophys Res Commun. 2009;385(2):154-159. CrossRef Medline

99. Wei Z, Wang J, Shi M, Liu W, Yang Z, Fu Y. Saikosaponin a inhibits LPS-induced inflammatory response by inducing liver $X$ receptor alpha activation in primary mouse macrophages. Oncotarget. 2016;7(31):48995-49007. CrossRef Medline

100. Murai T. The role of lipid rafts in cancer cell adhesion and migration. Int J Cell Biol. 2012;2012:763283. CrossRef Medline

101. Li YC, Park MJ, Ye SK, Kim CW, Kim YN. Elevated levels of cholesterol-rich lipid rafts in cancer cells are correlated with apoptosis sensitivity induced by cholesterol-depleting agents. Am J Pathol. 2006;168(4):1107-1118. CrossRef Medline

102. Zhang $\mathrm{H}$, Penninger JM, Li Y, Zhong N, Slutsky AS. Angiotensinconverting enzyme 2 (ACE2) as a SARS-CoV-2 receptor: molecular mechanisms and potential therapeutic target. Intensive Care Med. 2020;46(4):586-590. CrossRef Medline

103. Lu Y, Liu DX, Tam JP. Lipid rafts are involved in SARS-CoV entry into Vero E6 cells. Biochem Biophys Res Commun. 2008;369(2):344349. CrossRef Medline

104. Glende J, Schwegmann-Wessels C, Al-Falah M, et al. Importance of cholesterol-rich membrane microdomains in the interaction of the S protein of SARS-coronavirus with the cellular receptor angiotensin-converting enzyme 2. Virology. 2008;381(2):215221. CrossRef Medline

105. Wang H, Yuan Z, Pavel MA, Hobson R, Hansen SB. The role of high cholesterol in age-related COVID19 lethality. bioRxiv. 2020.05.09.086249. CrossRef 